\title{
OPERATING BUDGETS AND THE TURISTIC TRAFFIC PATTERNS AND THEIR IMPORTANCE.THE GOVERNMENT AND OTHER STAKEHOLDERS OF TOURISM.THEORETICAL TREATMENT ANALYSIS
}

\author{
PhD (Candidate) FRANKO BAGNIOLINI \\ University of Roma, Italy \\ Department of Finance and Accounting, Roma University, Italy
}

\begin{abstract}
Tourism development could be even bigger if more could be done in various elements of transportation systems. It is an important for all its stakeholders to take part to develop tourism in their regions. Tourism sector is one of the main important sectors of the economy. Many countries take advantage of covering the budget deficit with the help of profits coming from tourism. That is why tourism sometimes is called a factory without chimney. But tourism has its own unique features that differentiate this sector from the others. Like in the other service industries, in tourism the customers, that is, the tourists come to the destination where the tourism services are provided. As the matter of fact, it is difficult to think of tourism sector without transportation. Transportation is the main mean to carry passengers, that is, the tourists to the actual site where tourism services are performed (Mudsuman P) In the first models of tourist systems, the emphasis is placed on the components of the two regions' connectivity: that of tourism and the reception of tourists. Researcher Marioti, for example, proposes three routes for the movement of tourists from their permanent residence (origin) to the tourist region (destination), which are the entrance and exit routes, which in some cases coincide with each other and the entertainment route. While access and exit routes ensure the connection between the two countries, the entertainment route on the other hand ensures the use of touristic structures during travel even though these structures do not belong to the tourist destination. As we have noticed before, an effective accounting system is vital to the firm's success. Without the information provided by the management accounting system cannot make decisions. However, the quality of a firm's accounting system depends on the effectiveness of internal control within the firm. Internal control is a system of controls and balances that plays a key role in maintaining the firm's assets and in reinforcing the accuracy and security of financial reports. The importance of internal control is great in large corporations. Knowing the key financial concepts and the proper use of calculating and mathematical skills in personal finance situations are generally considered as a basic criterion for assessing a person as financially cultured. For this reason, the accurate measurement of these two criteria also constitutes one of the main objectives of the survey. This is to be achieved through a community of 8 well-studied questions that test respondents' knowledge on simple concepts such as: simple and compound interest, risk, return on investment, and inflation. In our analysis we will focus on the accounting system that provides users with both financial and non-financial information. Budgets, a tool often used, have been around for a long time.
\end{abstract}

Key words: International Control, Budget, operational data, Ministry of Finance in Albania and Kosovo, Empirical Study Accounting Empirical studies, interest, risk, Accountings politics, 


\section{JEL Classification Security System: N0, N1, N2, N3, O1, O2, 03.}

\section{Introduction}

Railway Transportation The other mode that affects tourism is railway transportation. This type of transportation is considered the oldest one. In 19th century the railways were frequently used. Currently in many countries the railways are used for transportation of loads. The reason for this is tourist choice of air or automobile transportation. But there exist such railroads that have been included to touristic packages. For the example, we can give Orient Express railways. But nowadays application of technology and technological innovation gave birth to fast trains which compete with air and automobile transportation modes. (Mudsman P) Internal control is necessary for auditing conducted by independent accountants. Certified public accountants refuse to give opinions about a company's financial statements if there is a lack of internal control. For example, internal control involves the separation of tasks, so that the individual that deals with asset control does not even deal with the recording of transactions in the books of accounting. Capital budgeting, however, does not fit well with many businessmen. This is partly due to the difficulties of preparing a capital budget. Cash flow assessments should be further delayed in the future and unfamiliar terms such as cost weighted average capital and internal rates of return, creep into terminology. Recent years academic studies have focused on emotions to explain the behavior of investors and the performance of financial markets. It should be noted that "Traditional finance theory" is built on the assumption thatinvestorsalwaysmakerationaldecisionshaving asingle objective, maximizing thebenefitinarisk environment and insecurity. The application of financial models means that individuals include information in the decision-making process using probability rules and statistics in calculations, leaving aside emotions. However, it should be noted that investors experience a series of emotions as they make a decision, and the more important this decision is, the stronger the emotions. Calculations related to these terms are often unrecognizable; many businesses have learned to operate without a formal capital budget.

However, properly used, a capital budgeting process can help reduce the risk of making the wrong decision.

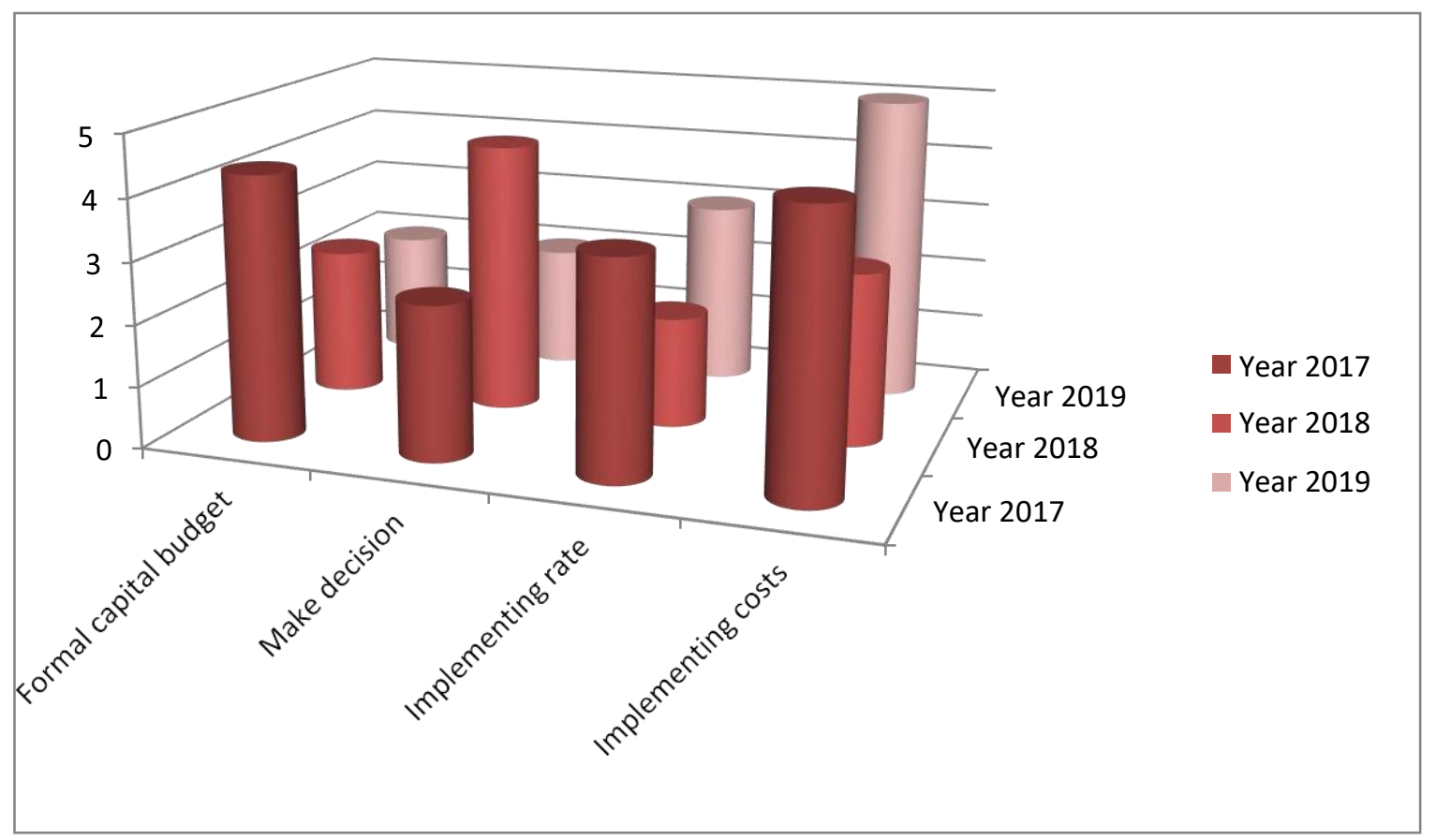




\section{Methodology}

The importance of developing an effective internal control system is not exaggerated. Additional efforts may be required to enforce internal control in a small company, where business procedures are informal and partitioning of tasks is difficult due to the limited number of employees. Even under such conditions, these checks must be carried out. Accountants can help solve problems that arise from lack of internal control. The Scientific research work will become more accessible and easier if it is based on the relevant built-in and verified methodology. The methodology that will be used during the drafting of the paper will be based mainly on the domestic and foreign doctrinal points of view. Not only is this a lost opportunity for investors to benefit from precious stocks in the market, but market exit at its low points hurt investors when they "sell less" and see no returns on their investments.

\section{The negative and positive emotion.}

Business liquidity is determined by the ability of the firm to repay debts and matured liabilities. We can answer this question in two ways:

Economic analyzes that have dealt with rational economic behavior have largely disregarded the role of emotions regardless of research on emotions, the description of the term "emotion" is defined very rarely. This paper upon the characteristics and features it carries is based only on the qualitative method of analyzing the issues addressed in it. It aims to answer the questions: How? Why? What's the way?

\section{Decision making process and importance of Constancy}

The answer is based on the calculation of the operating return on investment, which is measured by dividing the firm's operating income (profit before interest and taxes) with the total invested capital or total assets. In the traditional literacy and decision-making literature of a decision is mainly treated as a cognitive phenomenon and conceptualized as a goal or final point for a more complex process of reflection, which includes an assessment of the consequences and uncertainties. (Parkin 1996) determined the variables of a personal decision-making process consisting of five phases: Defining the Problem; thinking; trial; decision; and action. Parkin identified the impacts commonly affecting this process, such as behavioral history, beliefs, and situations. With all the research done today that includes emotions and choices, it is difficult to ignore the fact that emotion drives decision-making

\section{Literature Review and Hypothesis}

Researcher and Professor Svenson (1996) distinguished four levels of decision-making. The first level of decisionmaking processes involves many quick and mostly automatic and unconscious decisions. The decisions taken with respect to one or more attributes that favor the elected candidate belong to the decisions second level. The third level means that decision-making is a process that refers to choices between alternatives in relation to conflict of intent.

People can believe that their knowledge is more accurate than what they really are, may think that their skills are above the average can have an illusion of control or may be too optimistic about the future. Thus, aspects of others are taken into account when making decisions in uncertainty and people are more affected by perceived risk than objective risk (Diacon \& Ennew, 2001). Risk perception is an indispensable component of financial decision making and other risk-taking behaviors It is also necessary to make a distinction between risk and risk events.

\section{Research goal analyze}

The development of transportation, transportation vehicles, infrastructure and using new technologies in this sector speed up the development of tourism. If we pay attention to the statistics of World Tourism Organization, we may see that the tourism dynamics has changed and increased rapidly between 2005 and 2015.In 2010 international tourist arrivals rose to 940 million. This in turn brought the economies $\$ 980$ billion. This trend can be explained with different factors. But the main important factor here is the rapid development of transportation sector and application of technological innovations which enable the tourists to reach many destinations of the world.

Whether transportation plays important role in enriching the travel experience of a tourist depends on the mode of transportation and the frequency of use. Transportation can turn into a separate tourist attraction element; cruising, Orient Express trains, boat trips along the river and etc. are the best examples to tourist attractions. The effective 
factors in choosing the transportation mode in tourism are given below (Westlake and Robbins 2005, 463): Time limit during tourism studies, as an economic phenomenon, we are starting from the fact that tourists, as consumers of tourist services, travel industry, tourism and other similar activities are found on the one hand.

For example, the English author Likorish (Lickorich) defines the "passenger industry" as part of a national economy that cares for a traveler who visits places outside his country of habitation and permanent employment. The Passenger Industry is a heterogeneous group made up of a large number of trades and industries that have common functions to meet the needs of passengers.

All the stated issues prove the importance of transportation in tourism. As mentioned above the tourist's travel experience starts and ends with transportation. In this sense, if the countries want to gain sustainable development of tourism sector, they must pay attention to transportation sector, reduce monopoly in this sector; provide sound competition opportunities for the companies. This definition is the main basis for the definition of tourism as an economic phenomenon. Through the method of analysis, I intend to analyze the native and international legislation in place for the regulation of legal relations. In psychology, risk is perceived as a subjective construct influenced by the way an event is interpreted. Therefore, perceived risk differently from different people in different contexts. An analysis of how people make investment decisions confirm that objective probability estimates have only a weak impact on the decision-making process. Risk is defined as the probability of decision results in the context of expected service theories, which are applied to understand financial decision making.

Hypothesis: 1: The final evaluation, which was completed by the head of the institution, included the general evaluation with points, the general evaluation in words, proposals for further qualifications based on the evaluations, and also the head of the institution giving ideas of a different leveled job.

Hypothesis: 2: The scales of this evaluation were: especially well, well, enough, not well, inappropriate. On the other side, these elements would serve Albania to create a public administration based on the standards, which our country should have aimed for and realize them for the integration into the European Union.

1. The state role

2. The relationships of the government with community

\section{Conclusion}

Automobile Transportation In short distances automobile transportation comes forward in regard to other modes of transportation. The automobile transportation makes it easy to see local culture and nations. It presents great flexibility in contrast to other modes of transportation (Oter, 2007). The importance of this mode in tourism is also very important. When compared with the prices in air transportation, this mode of transportation is frequently used by tourists because of low prices. But the main factor affecting this choice is time and distance Railway Transportation The other mode that affects tourism is railway transportation. This type of transportation is considered the oldest one. In 19th century the railways were frequently used. Currently in many countries the railways are used for transportation of loads.

The reason for this is tourist choice of air or automobile transportation. But there exist such railroads that have been included to touristic packages. For the example, we can give Orient Express railways. Tourism is considered everywhere as an activity with intense development and high economic prosperity. From the analysis made in the development of tourism in many countries, there are many forms and models of development with its advantages and disadvantages, but which completely crystallize particular policies and programs of running this important economic branch.

Today there is a huge debate about the nature and breadth of the impact that tourism may have on the localities and host societies. Tourism is not only seen as a lucrative activity, but it is acknowledged that the costs and benefits are dedicated to its development. Many researchers have expanded the tourism impact analysis, including in its interior environmental, social and cultural considerations of the importance and intricacies that the tourism development is causing. When tourism impacts are related to its development, their analysis is mainly involved in tourism planning processes. The reason for this can be two-fold: Either the reformers may have implemented the wrong types of reforms or the civil servants may be resistant to reform since they feel that the present system is optimal for them and have created roadblocks for its implementation. 
ISSN 2661-2666 (Online) International Scientific Journal Monte (ISJM) DOI: 10.33807/monte/3/201912499 Volume 3 No. 1 (2020): April

We argue that the one of the possible reasons for this lack of impact might be because the civil service reformers have failed to fully understand the various performance evaluation systems, which in turn means that the system that has been implemented is the wrong one.

We also find that the majority of bureaucrats recognize that the present system is flawed and would be willing to accept a revised system that accurately measures and rewards performance.

In this article we look at the various models of performance management systems and narrow down the performance evaluation system that best fits the context. The evaluation of the performance is determined as an evaluation of the past and actual performance of an administration employee according to the standards organization performance.

The process of evaluation of the performance consists on:

1. The work standards.

2. The evaluation of the actual employee's performance related to these standards 
ISSN 2661-2666 (Online) International Scientific Journal Monte (ISJM) DOI: 10.33807/monte/3/201912499

Volume 3 No. 1 (2020): April

\section{References}

Emmett, Boris, and Jeuck, John C. Catalogues and Counters; A History of Sears, Roebuck \& Co. Chicago: University of Chicago, 1950.

Maslow, A.H. Motivation and Personality. New York: Harper \& Row, 1954.

Mayo, Elton. The Social Problems of an Industrial Civilization. Boston: Harvard Business School, 1945.

Mayo, Elton. The Human Problems of an Industrial Civilization. Boston: Harvard Business School, 1946.

McGregor, Douglas. The Human Side of Enterprise. New York: McGraw-Hill, 1960.

Taylor, F.W. The Principles of Scientific Management. New York: Harper's, 1912, and many editions since.

Wiener, Norbert. The Human Use of Human Beings. Boston: Houghton Mifflin, 1950. Woodward, Joan. Industrial Organization; Theory and Practice. Oxford University Press, 1965.

DCM no. 66, 03.02.2017, "On defining the criteria and the procedures for the establishment of medical university services and structures";

DCM no. 109, 15.02.2017, “On organization and performing of the Agency of Quality Assurance in Higher Education (AQAHE) and Accreditation Board (AB) and defining the fees of quality assurances processes in higher education";

DCM no. 329, 12.04.2017, “On the position and preferential treatment of the academic staff”;

DCM no. 370, 26.04.2017, "On the organization and performing of the high professional college"; 